\title{
Rules of engagement: Structuring sex and damage in men's prisons and beyond
}

\author{
SASHA GEAR \\ Criminal fustice Programme, Centre for the Study of Violence and Reconciliation (CSVR), South Africa
}

\begin{abstract}
This paper analyses data from a recent study of ex-prisoners and prisoners in Gauteng Province, South Africa, to consider the moral economy established by hegemonic inmate culture in which sexual interactions are negotiated. It argues that while this system is based on outside norms of heterosexism, ruptures with these norms occur. Male prison populations are rearranged into gendered categories through intricate inmate rituals, causing dramatic breaks in the ways that some prisoners are understood by others and themselves. The rituals and rules involved in the constructions appear to be unfamiliar from an 'outside' perspective, but have roots beyond prison walls. Similarly, the gendered positions generated are distinct from those they imitate, but also emerge in relation to them, beyond mere imitation. Even as new structures of identity emerge then, breaks with the outside are never total. Neither is the hold of the moral economy that inmate culture works so hard to create. Another order of rupture happens when prisoners transgress the rules of this economy, and subvert the meanings on which both the oppressive gender-sex status quo of the inside and that of the outside, rely.
\end{abstract}

\begin{abstract}
Résumé
Cet article analyse les données d'une étude récente sur des ex-prisonniers et des prisonniers dans la province de Gauteng, en Afrique du Sud, afin d'examiner l'économie morale établie par la culture hégémonique des détenus, au sein de laquelle des interactions sexuelles sont négociées. Il avance l'hypothèse que si ce système est basé sur des normes extérieures d'hétérosexisme, des ruptures avec ces normes se produisent. Les populations masculines des prisons sont reclassées en catégories "de genre " à travers des rituels carcéraux complexes, ce qui provoque parfois des ruptures dramatiques dans la façon dont les prisonniers sont compris par les autres et par eux-mêmes. Vus "de l'extérieur ", les rituels et les règles qui jouent un rôle dans ces constructions semblent inhabituels. Pourtant ils ont des racines au-delà des murs des prisons. De même, les attitudes sexuées produites sont-elles distinctes de celles qu'elles imitent, tout en émanant d'elles de manière plus affirmée que dans une simple imitation.Même lorsque ce phénomène entraîne l'apparition de nouvelles structures d'identité, les ruptures avec l'extérieur ne sont jamais totales, ni d'ailleurs le contrôle de l'économie morale que la culture carcérale s'acharne à créer. Un autre ordre de rupture se produit quand les prisonniers transgressent les règles de cette économie et ébranlent les significations sur lesquelles aussi bien le statu quo sexué et oppressif de l'intérieur que celui de l'extérieur s'appuient.
\end{abstract}

\section{Resumen}

En este documento se analizan datos a partir de un estudio reciente de exconvictos y prisioneros en la provincia de Gauteng, Sudáfrica, con el objetivo de examinar la economía moral establecida por la cultura hegemónica de los presos con respecto a cómo se negocian sus interacciones sexuales. Se arguye que si bien este sistema está basado en las reglas externas de carácter heterosexual, estas normas se acaban transgrediendo. Las poblaciones de presos de sexo masculino se reorganizan en 
categorías por sexos a través de complejos rituales entre los presos, causando cambios drásticos en la manera en la que los presos son entendidos entre ellos y por los demás. Los rituales y las normas que participan en las interpretaciones no parecen ser muy conocidas desde una perspectiva 'exterior', pero sus raíces traspasan las paredes de la cárcel. Al mismo tiempo, las posiciones por sexos que se generan están claramente definidas de aquellas a las que imitan, aunque también surgen con relación a éstas, más allá de la mera imitación. Aun cuando se originan nuevas estructuras de identidad, la ruptura con el exterior no siempre es total. Ni tampoco es la influencia de la economía moral que la cultura de convicto se esfuerza tanto en crear. Otro orden de ruptura ocurre cuando los prisioneros transgreden las normas de esta economía y trastocan los significados de los que depende el status quo del sexo opresivo tanto en el interior como en el exterior.

Keywords: Prison, gangs, rape, sexual slavery, homosexuality, masculinity, South Africa

\section{Introduction}

In South Africa, punitive popular attitudes to criminals refuse prisoners much public concern. Amidst high levels of violence and fear, society is tempted to conceive of prison as a black hole of nothingness into which criminals disappear forever. At the same time, what goes on in prison is regularly regarded as weird, perverse and fundamentally 'other' to the rest of society, more-so where the taboo-laden issue of sex is concerned. A consideration of the rules and assumptions that operate at the level of the dominant inmate culture to shape the circumstances surrounding sex in prison, points at once to the complex social world that prison environments in fact represent, as it does to their connectedness to patterns played out beyond prison walls. New forms of identity and behaviour are demanded by the intricate codes and rulings to which inmates are subject, but these constructions and negotiations while breaking with the outside, turn out to represent a precarious balancing of continuity with, and relationality to, more broadly experienced norms.

A central site of cultural power and rule-making in prison lies in gangsterism, particularly a collection of gangs known as 'the Numbers' (the 28s, 26s, 27s, Big 5s, Airforce 3 and 4). Operating along quasi-military lines that mimic the colonial militarized institutions to which they emerged in resistance, the Numbers have been around for more than a century. ${ }^{1}$ Each has specific objectives and code of conduct. The stated objective of the Airforce gangs, for example, is to escape from prison, while the Big $5 \mathrm{~s}$ collaborate with the authorities to obtain food and other privileges, and the 28 s protect and organize catamites or wyfies, as they are known, for sex. However, that actual gang practices diverge from the ideal codes is evident in the fact that all the Numbers gangs are apparently involved in the organization of specific sex interactions and relationships, even those where the formal codes expressly forbid it. Indeed, an investigation of sex in prison points to the multiple, sometimes contradictory layers of code and meaning employed in the organization of particular sexual relations.

Rules, codes and meanings surrounding sexual practices in prison construct and police particular gendered identities. Gender and sex relations in prison however, cannot be adequately explained by either the gang codes that so seek to regulate prisoner behaviours, or by dominant processes in South African society to which they powerfully link. Rather, the identities and relations produced in prison are the work of an uneven confluence of discourses incorporated from the outside and others generated by the inmate culture on the inside (both of which represent complex and dynamic processes in themselves). In their negotiations of sex and gender, prisoners exaggerate, adapt and break the rules, sometimes more vehemently asserting oppressive power claims, and other times, subverting them. In the process, new configurations of identity and interaction emerge. 


\section{Carceral identities: Imitation or rupture?}

Approaches to the production of sexuality and gender in South African male prisons are usefully informed by perspectives in historical accounts of sexual practices amongst men who were housed in South African mine compounds. A central debate has emerged in theorizing the relationship between sexual interactions and identity formation in South African carceral (Dirsuweit 1999) institutions, viz. mine compounds and, more recently, prisons. Subsequent to an initial break with the notion of these closed institutions as sealed off from processes in broader society, ${ }^{2}$ scholars divided on the question of whether inmate identities and sexualities represent a smooth transitioning consistent with outside identities or whether a rupture (Achmat 1993) occurs between previously existing identities from the outside and those experienced during incarceration.

In their considerations of sex relationships amongst male migrant workers housed in mine compounds van Onselen (1984), Moodie (1994) and Harries (1994) argued that the gendered identities forged around and central to relationships known as mine marriages ultimately cohered with the miners' lives outside. Through a variety of cultural networks, the incorporation of home practices into the compound, and the performance of particular roles inside in the interests of achieving a status at home, compound identities were intimately tied to their home lives, and the compound connected to spaces beyond it. These writers describe the particular moral economy of mine marriages that took place between older men and younger boys, the senior man assuming a masculinized role and taking the younger as his wife. In return for financial reward wives were required to perform a passive sex role and to provide domestic services to their husbands. In these accounts, the norms of these marriages are traced to exchanges and identity structures operating in the miners' rural home communities, which were based on gerontocracy and patriarchy.

A 'natural' end to the marriage occurred when wives grew older and could claim a masculine status and the active sex role that went with it, taking wives of their own (Moodie 1994: 127). This was a signal of status, and for a number of reasons, the 'town women' were a less desirable sexual alternative. The danger of venereal disease and theft, fear of losing one's rural identity and acquiring additional responsibilities by becoming tied to women in the town apparently contributed to the preference for 'mine wives'. However, in mine wifehood too, masculine purposes were being achieved. Because the passive, feminized role was financially lucrative it enabled the young man to build his rural resources and pay bride wealth. 'Being a "wife" on the mine', Moodie (1994: 134) argued, 'for all its apparent gender reversals, eventually reinforced the potential for male hegemony at home'.

Achmat (1993), and Dirsuweit $(1999,2003)$ have criticized this vein of analysis. Achmat (1993) argues that the sexual practices taking place in compounds could not be reduced to their relation to the rural communities and outside preoccupations, nor should we be intent on uncovering motivations for participation. Rather, he maintains that the compound 'partially freed the male body in its enslavement' (Achmat 1993: 106) allowing 'a definitive change in the relations between the concepts of sexual pleasure and sexual reproduction' (Achmat 1993: 108). The compound or prison is thus conceptualized as a 'rupture' that, by breaking with inhabitants' outside lives, presents possibilities for them to explore new configurations of desire and pleasure (Achmat 1993, Dirsuweit 1999, 2003).

Neither of these positions, ventures Dirsuweit (1999, 2003), adequately explain the sexual identities lived in carceral institutions. In her overview of the debate, she traces the different conceptions of the relationship between space and identity at play in these competing arguments. While the van Onselen (1984), Moodie (1994) and Harries (1990, 1994) analyses suggest that identity remains constant through space and inscribes each new 
space with meaning, Achmat (1993) considers the compound/prison to have constituted a new space discreet from traditional society in which miners were able to recreate themselves (Dirsuweit 1999). Dirsuweit contributes an alternative conception of identity. Following Keith and Pile's (1993) understanding of space and identity as in dynamic interaction, 'where both define each other in an unstable process which is constantly shifting and being renegotiated' (Dursuweit 1999: 72), she argues that it is 'conceivable that the ... traditions of rural communities were carried into the mine ... while at the same time ... the entry into a new space free of the norms of tradition and custom allowed them to explore same-sex desire in relation to cultural codes of other spaces, and through renegotiations of the mine codes of conduct as their sexual identities shifted' (Dirsuweit 1999: 72).

Dirsuweit's $(1999,2003)$ analysis of sexuality in South African women's prisons draws on Butler's (1990: 141) notion of gender as performative and as constituted by a repetition of acts as opposed to an expression of a pre-existing identity. She argues that the female inmates' construction and negotiations of sexual and gender identities, while 'based on norms of heterosexual interaction held in broader South African society', also fundamentally unsettle the discourses surrounding these norms in their shifting performances of gender (Dirsuweit 1999: 82). 'Even if the roles ... mirror male-female gendered relationships, they still serve to question what basis there is for claims to male privilege'. By identifying as men, asserting dominance over women and an exclusively penetrative sex role, for example, 'butch' prisoners in female prison endorse dominant gender relations, but at the same time hold up for parody the notion of gender as the natural and stable outcome of a particular sex. This is more-so, on the part of some who do not restrict their enactment of gender to this singular 'masculine' identity. The threatened responses such inmates evoke in heterosexual prisoners and correctional staff, Dursuweit argues, is testament to their subversive quality.

Dirsuweit's (2003) conception of the cultural environment is a valuable point of departure. This, she presents as the particular but changing results of a complex interplay of discourses emanating from, and in interaction with a range of spaces and power sources. In these interactions breaks are made, boundaries pushed and shifts in understandings of self and others possible.

The carceral environment then can be approached as the intersection of different discursive structures which are not only based in state control, but also find their roots in prisoner based discourses and in the discourses of other institutions and cultural formations. In other words, the prisoner's subjectivity is produced outside of the carceral environment and in discursive formations within the prison which intersect with, but are not necessarily controlled by state authority. At the same time, carceral institutions present a rupture in established identity structures. (Dirsuweit 2003: 64-65)

In exploring sexual practices and the production of gendered identities in South African mens' prisons I follow these theoretical conceptualizations of identity and the carceral environment. The goal is to open up questions of continuity and rupture in relation to the construction of gender, and propose a conception of rupture that is broader and more multinatured than the existing work suggests. I argue that some of these breaks in fact occur because of continuities with outside norms. As a result, they also organize in contradictory unevenness between differently placed actors, and between levels of social organization.

In this study, in-depth interviews and focus group discussions were held with 23 prisoners and ex-prisoners in Gauteng Province, South Africa. Data were analysed thematically so as to focus on the above concerns. 


\section{Prison marriages and the sexual status quo: Rules and roles}

Male prison populations tend to be divided into people identified as 'men' and those identified as 'women'. 'Women' are seen primarily as the sexual property and servants of 'men' and are often forcibly taken as 'wives' (or wyfies) by other inmates in relationships known as 'marriages'. ${ }^{3}$ They are required to take care of the 'home' space (cell) and to be sexually available to their partners. 'Men'/'husbands', on the other hand, provide materially for their 'wives' through activity in the 'business' of prison. ' 'Marriage'-type interactions are reportedly the most common site of sex in men's prisons and are accepted in the hegemonic inmate culture as the right place for sex to happen. Like in accounts of sexual mores from the mine compounds (Moodie 1994) and women's prisons (Dirsuweit 1999, 2003) they arrange around a conflation of gender and sex role: men penetrate and women are penetrated.

Gang structures are intimately involved in the construction and regulation of 'women'. Members are divided between two ranking hierarchies: one of 'masculine' ranks and the other of 'feminine' ones. Each masculinized rank corresponds to a feminine one, determining which 'women' will be allocated as wyfies to which 'men'. Higher ranking 'men' have the greatest entitlements to sex. Intricate rituals and regulations are in place to organize the maintenance of this sex and gender status quo. An ex-prisoner explained for example, how wyfies in the Big 5's gang are schooled in their roles by the wyfie at the helm of the feminine hierarchy.

The Star [is] ... the first [wyfie] in the Cabinet and all the [others] listen to her. He teaches them what ... we do not want in Big 5: ... 'If you stay with a person you have to treat him this way and not that way because if you do, you make him angry' ... They cannot tell us [men] that they do not like sex. The Star will tell them that they must not say things like that.

But fundamental to the controlling of 'women' and sex relations at the levels of individual partnerships, gangsterism and also beyond, are the codes contained in public myths and discourses that have a grip on society more generally. These are behind the sexualized and inferior way in which women are seen, the passivity expected of them, the entitlement of men to sex from women, and the powerful perception that victims of forced sex in prison are, like those out of it, in some way to blame for what has happened to them. (See, for example, Jewkes and Abrahams 2000, Zulu 2001, CIETinternational 2003.) These meanings militate towards silence on the part of victims. ${ }^{5}$ Sexual violence is constructed as a gendering experience that changes men into 'women', and 'real men' do not allow themselves to be raped. Respondents testify frequently to the potency of these public myths in, for example, their certainty that were the family of a prison wife to find out what had happened to their relative in prison, his identity as a man and his role in the family would be demolished.

His wife and children [will think], 'You're nothing! After all, you've been raped; you are just as good as we women'... Of course he can't tell his family!!

\section{Making women, taking wives}

The polarized gender categories that this moral economy requires demand that some inmates depart from the way they have up until their incarcerations understood themselves and been understood by others. A range of rituals and methodologies are employed to bring about these breaks and to re-allocate gender identities for the inside. 
A typical path into being made a 'woman' and 'wife' is for a new offender to accept food, drugs or protection from another prisoner. Lacking prison 'suss', first-time offenders are especially vulnerable to the manipulation regularly employed by other inmates. They do not know that by accepting what was on offer an exchange is understood to have taken place and a debt created. Later, the new offender will learn that he is expected to make good this debt by providing his 'provider' (the person from whom he accepted food, drugs, etc.) with sex. When trying to refuse, he will learn that there is no way out. Most marriages reportedly begin in this way with the provider forcing sex with the person he subsequently takes as his 'wife'. Being sexually penetrated is understood to confirm 'womanhood'.

Accepting what is offered by another (who likely presents himself as a generous being in a sea of hostility) is to display naivety and trust, qualities that are understood to signal inferiority, weakness and 'woman-ness'. Poverty is also associated with femininity and poor prisoners, frequently those who do not get visitors - a source of commodities and moneytend to be amongst those forced to join the ranks of 'women'. Physical weakness or unwillingness to use violence as well as 'good looks' (apparently encompassing smoothskinned youthfulness and plumpness) are said to make for likely targeting. But respondents emphasize that none of these characteristics are absolute prerequisites for being sexually subordinated and designated 'woman'. Some people are targeted until submission regardless of the way in which they conduct themselves. This is where overt violent rape gets most mention.

The rules in this one-sided game are therefore almost as changeable (on the part of the player) as they are hidden from those being played. Their hidden nature is central to the subordination strategies, but where these, despite the deception, do not produce the desired results they may be ditched for other less veiled ones. Nevertheless, the fact that they exist at all, may be employed in justification of the acts (other times dismissed as 'natural' entitlements).

Obviously a prisoner's things are going to talk. I cannot give you a cigarette and then go [away and not bother you again]. So if you do not understand [stops short].

In jail terms ... I cannot just give a person 20 rands and buy anything I want to buy him; and tomorrow he says that I have raped him.

Other explanations work to naturalize the establishment of the gender category that the acts bring into being.

You can never allow another man to come on top of you if you do not like it.

Promotion from 'womanhood' to a masculine status is rare, and only available to those who are able to prove a claim to 'manhood', usually via the performance of particular violence. In addition to a preparedness to use violence and ability to fight, markers of manhood reside in a portrayal of self- sufficiency, aggression and deviousness.

These assertions and pronouncements on gender strongly resonate with others experienced between men and women in South Africa. The notion of a sex-debt accruing on acceptance of money or gifts (Wood and Jewkes 2001, Vetten and Bhana 2001) and the wrapping up of violence with ideas of manhood (Wood and Jewkes 2001, CIETinternational 2003, Selikow et al. 2002) are amongst many others.

Clear discontinuities with the outside are also presented. The possibility of being tricked into a state of 'womanhood', for instance, breaks with established gender enactments. At 
the same time, though, what targets are being tricked into, is behaving in a way that can then be claimed to invoke more familiar assumptions about gender that are based on its dominant construction into either/or categories (where 'men' are providers and protectors, and 'women' are dependent and vulnerable). They are tricked into behaving in a way that's associated with 'woman-ness' or, the other side of the coin, accepting a show of 'man-ness' from another (which, in the way of binary oppositions, positions them as 'women'). This is one avenue through which the constructions are 'naturalized'.

Trickery, then, can be understood to effect a rupture with the outside that is necessary for the broader reproduction of 'heterosexuality' inside. (Unfamiliarity is exploited in the reconstruction of the familiar.) The break or rearrangement that is necessary is the creation of 'women' out of men. Moreover, trickery performs a related role of smoothing over these breaks in attempt to invisible them and stabilize, via reference to outside discourses and established gender assumptions, the 'women' identities it jolts into action.

With trickery being one of the corner stones for the building and maintenance of the gendered sex system in prison, respondents emphasize the manipulation and deviousness, which targets are up against.

You have to be careful of what's happening around you in jail. You need tactics and you have to know your story ... Some people like sex ... They won't force you, they will manipulate you. They do it well. You can refuse and refuse, but you'll end up doing it because they will work on your mind.

I lie to him ... I just twist his mind. After I have twisted his mind, he is going to ... give me [sex].

At the level of the gang, trickery and manipulation feature big in recruitment. Stories of sex may be directly implicated in gang members' engineering of increased fear levels in a bid to secure new recruits. A former Airforce 3 member explained how, in that gang, sex is used as a topic of recruitment-speak. By cashing in on both fear of forced sex and/or disapproval of male on male sex, new members are persuaded to join.

I'll tell him that Airforce 3 do not indulge in prison activities like homosexuality ... He'll [think] ... 'If I can be one of these gangsters, I'll be in the right hands'.

Some of those, for whom a prime motivation for joining may have been the belief that sex is not practiced in that gang, are subsequently made into 'wives' of other members.

That the meanings and identities surrounding sexual practices in prison cannot be reduced to their relation to norms of outside society, nor explained as the particular creations of a disconnected prison space is shown in this Airforce 3 member's recruitment strategy. While prison 'marriages' are organized so as to distance the sex that happens within them from notions of homosexuality, they may at the same time be referred to as just this, in order, paradoxically, to secure 'heterosexual' objects. A boundary between heterosexual and homosexual, key to the construction of hegemonic gendered sex relations, is thereby momentarily pushed, again with an act of trickery, so as to rearrange heterosexuality for the prison context.

\section{Gang rituals of gender allocation ${ }^{6}$}

In the Airforce 3 gang, a classifying ritual that reportedly allocates gender to new members also depends on hidden codes. The ritual is performed by an official known as the 'Blacksmith'. 
[The new guy] knows that homosexuality is not being practised [in the Airforce] but ... once you are in the office ${ }^{7}$ of this guy called Blacksmith ... he is going to trick you into having sex ... He must classify you ..., whether you are a young man ['woman'] or ... a full soldier ['man']: 'Look, ... there is the camp of full soldiers and the camp of young soldiers ... [To] be a full soldier, ... you've got to know that you'll be working with blood ... We give you a knife and say, "Go and stab so-and-so" or "go and stab a warder". . Now the young man will ... think about the beating up that he'll get from committing such a crime ... He already has this tattoo and has been told that ... if he takes it out ... he's going to die ... He must choose to stab or he must choose to be a young man ... Once he says he falls into this camp of young soldiers, ... then the Blacksmith will say Ungcwalisele ('make me believe you') ... [that] you can be a young soldier ... He'll say, 'Okay' ... [without having] any idea of how he must convince this guy. But ... the blacksmith has the intelligence of speaking ... —of scaring him - ... [so that] he must be compliant ... 'Come'. Maybe they go to the shower ... (soldiers are standing guard outside ... keeping watch for the warders). 'Take off your trousers' ... [The Blacksmith's tone] has changed now. The young man will see, 'Aish! I haven't got a chance ... I must agree with everything that this man says'. Maybe he'll say, 'Ay man, I don't like this thing'. [The Blacksmith] will say, 'No! ... you've already taken my tattoo and you want to tell me stories!'

According to this respondent, a literal sex act (usually rape) follows for those who do not commit to proving their capacity for violence. But both the meaning of what a 'young soldier' role entails and the centrality of violence to retaining a claim to 'manhood' are not available to the new recruit.

Another account of a gender classification ritual in the Big 5 s gang powerfully elucidates the resolve to establish gender identity as a natural and biologically determined fact. New members are sent to an official known as the 'Medical Doctor' who is responsible for classifying them as either 'Soldiers' (men) or 'Free Moscows' ${ }^{\prime 8}$ (women). The Doctor performs a ritual of listening to the pulse of the recruit. Depending on the number of kloks that he 'hears' flowing in the blood, the recruit is designated as either 'wyfie' ('free moscow') or 'soldier'.

He must put your hand like this. [Q: He holds it at the pulse?] [yes] and he says fou bloed klok 25 male getale van vier. (Your blood beats 25 times 4). 'Times 4' means you are Section 4 which means you are a free-Moscow. If you are a big man I say [that] your blood beats 25 times 5 . That means your blood is full, [that] you are a soldier. The medical doctor ... must hear how many times your blood kloks.

The pulse rate detected by the Doctor, explained the respondent, will be determined by how the recruit has come across to the Doctor in a preceding conversation. The Doctor will be assessing, 'Can [I] see that this guy is a small guy [i.e., woman]? Yes he is a small guy'. The placing of the new recruit through the ritual appears quite often to represent the rubberstamping of a decision already made elsewhere-in the regular auditioning and testing of unknowing subjects for gendered parts.

For all the ritual's apparent strangeness, multiple discourses and processes that have their roots beyond prison walls are put to work in the naturalization of gender construction. Key is a discourse that situates the medical fraternity as holders of irrefutable truths about the body, and as Butler (1990) and Foucault (1992) have shown, medical discourses have regularly been drawn upon in the construction of cultural norms around gender. Via the Medical Doctor the discourse that has medical knowledge equated with natural truth is incorporated, and a sense of the fact-full-ness of gender classification sought. In the absence of recourse to sex as the 'source' of gender, the ritual of pulse-listening by the gang's Doctor makes a medical pronouncement rest on a reconstituted body where the truth of gender lies resident in blood flow. 


\section{Deconstructing masculinity: Un-man-ness, a state of prison woman-ness}

Overall, the processes and languages through which the dominant construction of gender occurs in prison can at once be understood as breaking with those on the outside (the newcomer's unfamiliarity with them is regularly central to the process) and fundamentally connected to them. Starkly evident is the imperative to ensure the reproduction of what Butler (1990: 35) conceived of as the 'heterosexual matrix' where subjects are categorized into stable genders that express stable sexes that are 'oppositionally and hierarchically defined through the compulsory practice of heterosexuality' (Butler 1990: 151). In this context, the requirement for opposite stable sexes is translated into that for oppositional stable sex roles (active penetration or passive receiving).

It is precisely the drive to re-establish this outside arrangement that is simultaneously behind the sudden and decisive break from existing identity structures that is experienced by some prisoners in the forcible reconstruction of them as 'women'. The mightiness of this break follows from the oppositional and hierarchical construction of gender where one category is brought into being by its difference to the other, and in this way (hegemonic) masculinity 'precariously achieved' by the insistence of total (superior) opposite-ness to femininity (and homosexuality) (Weeks 1985: 190). The individual is inserted into the position that up until then defined what he is not. He is situated as his erstwhile 'other'. At the broader level, however, the status of 'compulsory heterosexuality' is affirmed.

But the break affected at the individual level through the loss of the 'script' of masculinity is not clean or total, nor the transition into a 'woman' role, smooth. More often it seems to be characterized by they vying of competing oppositional identity constructs. This is the experience of much more than the contradictory and tenuous nature of different identity positions 'our irreducible scrappiness' (Smith, cited in Gutterman 2001: 57) that constitute all subjects.

The part of very direct initial force in the imposition of the 'woman' script as opposed to the more subtle workings of general discourse power leads to a markedly conscious enactment of that gendered role: he submits to appease others and prevent consequences of not going along with the performance. However, this enactment of 'woman-ness' (more conscious as it may be) and the demands of dominant gender discourses throw his sense of his 'man-ness' into question. ${ }^{9}$

Prison 'womanhood' is distinguishable from the dominant 'womanhoods' of broader society, in large part because of the demolished 'man-ness' it is understood to involve. As such, it is thoroughly shaped by a previous outside identity. The extent to which this is so provides exaggerated illustration of the inevitable inclusion in emerging normativities, of existing dominant discourses: the former are expressed in relation to the latter (Butler 1990, Gutterman 2001, Dirsuweit 2003). As one respondent viewed it,

They will hate themselves so much for having lowered themselves, for having not been man enough to stand [up] against other men.

Another, in his explanation of the shame and silence typically surrounding the forced enactment of prison 'womanhood', pointed to a difference he perceived in the responses to sexual violation between 'women' inside, and their outside counterparts.

Men are controlled by pride, they are so secretive about bad things that happen ... They will never go for counselling, they will keep quiet ... Men are not like women. Women ... come up with things like [the concept of] 'rape survivors'. Men will never. 
Dominant prison culture, in its emphatic enactment of heterosexuality insists on the stability of genders, and unlike on the mines, where a coming of age saw a gender reorganization, for prison wyfies there is no 'natural' end to their feminized status. Immediately available routes whereby the status could be incorporated into the achievement of a broader 'masculinity' are not forthcoming. In addition, as suggested by the ex-prisoner cited above, they likely lack tools for the integration of their sexual violation that would potentially be available to them were they 'outside' women. New processes in identity formation, distinct from those outside, are therefore brought into being in moments of gender positioning in prison. This, while they are the productive work of the same discourses that structure gender in broader South African society.

\section{Transgressive ruptures}

The breaks with existing identity formations outlined above are a far cry from the ruptures that Achmat (1993) had in mind when he called for the abandonment of heteronormative readings of prison sex, an acknowledgement of pleasure and desire in explanations of prison sexual practices, and a recognition of the freedom to explore these that could come in the removed spaces of prison environments. In contrast, the ruptures focused upon here, wrought for many prison wyfies depart both in their brutal nature and in the very direct links to (mimicking of) the dominant discourses that have a grip on society more generally. Indeed it is through the enactment of the demands of some of the most oppressive of these dominant discourses that dramatic change is forced.

At the same time, the re-construction of heterosexist relations in prison, expose a notion of a fixed and essential gender identity to be, quite literally, the result of tricks. The typical relations that surround the widespread practice of gender production - the breaking-in of prison 'wives'-show up the performativity of identity. Having unknowingly been auditioned for gendered parts, wyfie candidates are forced into performances of 'womanhood' and the 'regulatory fiction of heterosexual coherence' (Butler 1990: 136) (which has fixed gender following fixed sex) loses its footing. However, Butler's contention that 'parody [of gender-sex coherence] by itself is not subversive' (1990: 139) is invoked when the relations produced in the process seem for the most part, to exaggerate and intensify tenets of patriarchal and heterosexist oppression. But this is not the whole story. While the workings of gangs as the explicit guardians of inmate culture are concerned with the strict regulation of sex in prison, and with closing the spaces in which alternative modes of relating can be negotiated, these are not total, stable, or fully successful.

Ushintsha ipondo is one type of interaction that transgresses the rules of prison sex, is treated as deviant and officially outlawed by the gangs. Even so, it is reportedly the most common type of sex interaction after the 'marriage' style variety. Literally meaning 'to exchange a pound', it is defined in terms of how the sexual interaction takes place: as an equal exchange of sex for sex. In this type of sex, both the power dynamics and the related rules of interaction associated with 'marriage'-type sex are undermined. It is marked by its consensual nature and often articulated as 'doing each other favours' or 'taking turns to be the man'. Participants, neither of which is considered inferior or superior, take turns to penetrate and receive. And herein lies its subversiveness: by both penetrating and receiving they are disrupting the system that allocates a gender identity on the basis of a restricted sex role. This blurring of gender roles also results in an association of the practice with notions of homosexuality. To participate in the practice is reportedly to invite punishment or extortion to keep it quiet. 
Indeed, gangs claim exclusive rights to sex in prison (despite considerable contestations around sex within the gangs). Members police the 'who' of sex interactions ('one-ones' or mphatas as non-gang members are known, are not supposed to be involved) as well as attempting to rule on types of interaction. In relation to the practice of ushintsha ipondo, respondents explain,

That is not allowed at all by gangsterism. Those people are just taking their chances; they make sure they're not caught.

They've got to be very careful and very secretive because once they are seen ... it's a very serious matter.

Or, some suggest, it may involve negotiations and discretion rather than instant punishment. While respondents unite in reports that partaking in ushintsha ipondo is dangerous, levels of conditional tolerance would appear to vary depending on, for instance, intensity of gangster presence-or others seeking benefits from contraventions of sex rules, and the individuals involved. Participants are commonly young prisoners who are simultaneously the 'wives' of other inmates. Some respondents suggest that where such participants might get away with discretion, the older and more 'masculinized' the participants, the more heinous is considered the crime and threat to the status quo.

I've seen [older men doing it as well] but it's more scandalous than that of the younger people ... No officer of a gang can do that. His gang, hey! They can—ay, ay, yay, ay!!

The uneven turning of a blind eye may find its roots beyond prison walls in relatively strong expectations in some South African communities of sexual experimentation amongst preinitiated youth (Wood and Jewkes 2001, Glaser 1998 and Mager 1998 cited in Wood and Jewkes 2001). In contrast, the involvement by senior masculine-identified participants pose a far greater threat. Such individuals are at the centre of the sex-gender power structures and as Gutterman (2001: 68) put it, 'The more central an element is to a system in power $\ldots$ and the more fundamental that system is in the grander scheme of structures of cultural order, ... the more the "deviant" identification or behaviour will be contested and ostracized'.

Out of widespread oppressive relations then, other configurations emerge that challenge the assumptions of both inmate codes and the broader norms on which these are based. In the case of ushintsha ipondo the disruption comes with a refusal to solidify and make stable the gender categories brought into being, and on which the system relies. It could be argued, that these emergent but transgressive behaviours are the productions not only of the partial freeing of the male body 'through its enslavement' by the prison regime as Achmat (1993: 106) argued, but that at the next level down of enslavement, in the 'marriage', a form of partial freeing may also occur. Having been brutally initiated into the myth-fullness of stable-gender as expression of stable-sex, some wyfies, in seeking out pleasure, then play with, and refuse the demand to stabilize, the roles enforced on them. (As such, ushintsha ipondo could also represent an expression of some measure of integration around a 'not-man-not-woman' status.)

More generally, while the dynamics surrounding two of the reportedly most common modes of sexual interaction have been broadly sketched here ('marriage' and ushintsha ipondo) a potentially vast range of circumstances surround prison sex, which are negotiated by numerous and diverse individuals and takes place in varied contexts. The unstable 
nature of gang identity and influence must also be emphasized. As already mentioned, gang rules are regularly internally inconsistent and shifting. Moreover, their memberships are differently tied to the meanings that make sense of these, some being embedded in them and others largely ignorant; and while respondents speak of what 'the gangs' do, they are also far from homogenous. Within gangs, sex and sexual violence specifically are contested issues.

In addition to marriage-mode, and ushintsha ipondo another category of sex interactioncontained in relationships defined by the 'love' feelings existing between participantsmakes a brief appearance in some interviewee accounts. Alternative modes of relating may also be negotiated in the little pockets of privacy that prisoners create for themselves, even when they ostensibly resemble particular 'types' of interaction. The nature of interactions also changes through time. In the process, diverse negotiations of sexuality and gender will be enacted. Many more of these require future research and attention.

\section{Conclusion}

New forms of identity and behaviour are demanded by the intricate codes and rulings to which inmates are subject, but these emerge as neither wholly 'new' and confined to the 'inside' or pre-existing and traceable to the 'outside'. Rather, constructions and negotiations of sex in prison represent a subtle balancing of adaptation, continuity and rupture with more broadly experienced norms.

Paradoxically, in the male prison, it is precisely the mimicking of the 'outside' arrangement that conflates sex and gender that sees, for some inmates, defining breaks with their lives outside. The break comes as wyfies are positioned as the very difference (womanness) that has up until that point, defined what they are not, the 'other': hegemonic 'masculinity' is maintained by the insistence of total and superior opposite-ness to femininity (and homosexuality). While there is need to guard against blanket assumptions in relation to the state of prison 'wifedom', at an individual level, for many a wyfie dramatic discontinuity is wrought as they are catapulted from one end of the gender hierarchy to the despised other. But, at the level of the framing paradigm, patriarchal heterosexuality is 'compulsively' (Dirsuweit 2003: 76) maintained.

The ruptures and rapid generation of hybridized versions of self are multi-natured at the same time as they are characterized by unevenness amongst actors. While the requirements of 'manhood' in prison may be particularly exaggerated, those who continue to achieve enough of it (to maintain a 'man' status) will not experience a comparable break in the sense they make of their gendered selves to that experienced by 'women'. Different types of discontinuity or rupture are also distinguished. In contrast to that affected by the re-positioning of men as 'women', transgressive ruptures are brought about as prisoners break and push the gender-sex rules dictated by both inmate codes and patriarchal heterosexuality, thereby deconstructing the assumptions on which they rely.

\section{Acknowledgments}

Thanks to Teresa Dirsuweit for invaluable supervision support, to Kindiza Ngubeni for his co-researching; and to the CHS reviewers for their comments. I am grateful to Amanda Dissel, Mona Saungweme, Ebrahim Fakir, John Gear and David Bruce for commenting on early drafts, and to Liz Walker, Penny Ploughman, Graeme Reid, also Bilkees and Irshaad Vawda, Fraser Gear and Rishy Singh for their support. Thanks to Ireland Aid (now Development Cooperation Ireland) for making the research possible. 


\section{Notes}

1. According to van Onselen (1984) these gangs originated outside of prison. See also Haysom (1981).

2. Van Onselen highlights the extent to which imprisonment in South Africa has historically been intertwined with the migrant system, with the 'pass laws ensuring a constant flow of men into and out of prisons' and causing constant articulation between 'prison, mine compound and black township alike' (van Onselen 1984: 23).

3. Other terms that refer to prison 'women' are 'small boy', 'young man', 'madam' and 'girlfriend'. In this article the terms, wife, wyfie and women are used for ease of reference.

4. Participation in smuggling networks is a key activity.

5. This is bolstered by other pressures ranging from death threats to the dictates of prevalent inmate culture concerning interaction with authorities.

6. We did not interview long-standing members of the $28 \mathrm{~s}$, the gang most often associated with taking wyfies, but that our most detailed insights into the relationships of gangsterism and sex come from members of other gangs, is suggestive of the extent to which specific sex relations are institutionalised in inmate culture. Also note that the detail of the rituals outlined here was provided in the individual testimonies of specific long-standing members.

7. 'It's an imaginary office in a cell somewhere' he explains. In addition, 'office' refers to the position of the official.

8. The Free Moscow category consists of the most junior 'women' in the gang.

9. The extent of irreconcilability of the two competing scripts of gender enforced onto many a wyfie subject, and dictated by the discourses of hegemonic heterosexuality perhaps constitute a point of 'trauma' from a performativity theory perspective.

\section{References}

Achmat, Z. (1993) 'Apostles of Civilised Vice': 'Immoral practices' and 'unnatural vice' in South African prisons and compounds, 1890-1920. Social Dynamics 19, 92-110.

Butler, J. (1990) Gender Trouble: Feminism and the Subversion of Identity (London: Routledge).

CIET international. (2003) Beyond victims and villains: The culture of sexual violence in South Johannesburg. Available at: http://www.ciet.org/www/image/country/safrica_victims.html

Dirsuweit, T. (1999) Carceral spaces in South Africa: a case study of institutional power, sexuality and transgression in a women's prison. Geoforum 30, 71-83.

Dirsuweit, T. (2003) Geographies of carceral institutions: A case study of a South African women's prison, PhD thesis, University of Witwatersrand, Johannesburg.

Foucault, M. (1992) The History of Sexuality: Volume 2: The Use of Pleasure (London: Penguin).

Gutterman, D. (2001) Postmodernism and the Interrogation of Masculinity. In S. Whitehead and F. Barrett (eds.) The Masculinities Reader (Cambridge: Polity Press), pp. 56-71.

Harries, P. (1990) Symbols and Sexuality: culture and identity on the early Witwatersrand gold mines. Gender and History 2, 318-336.

Harries, P. (1994) Work, Culture and Identity: Migrant Labourers in Mozambique and South Africa, c1860-1910 (Johannesburg: Witwatersrand University Press).

Haysom, N. (1981) Towards An Understanding of Prison Gangs, Institute of Criminology, University of Cape Town.

Jewkes, R., Abrahams, N. (2000) Violence against women in South Africa: rape and sexual coercion (Pretoria: Women's Health Research Unit: Medical Research Council).

Keith, M., Pile, S. (1993) Introduction part 1 and Introduction part 2. In M. Keith and S. Pile (eds.) Place and the Politics of Identity (London: Routledge).

Moodie, D., Ndatshe, V. (1994) Going for Gold (Johannesburg: Witwatersrand University Press).

Selikow, T., Zulu, B., Cedras, E. (2002) The ingagara, the regte and the cherry: HIV/AIDS and youth culture in urban contemporary townships. Agenda 53, 22-31.

Van Onselen, C. (1984) The Small Matter of a Horse: The Life of 'Nongoloza' Mathebula, 1867-1948 (Johannesburg: Ravan Press).

Vetten, L., Bhana, K. (2001) Violence, Vengeance and Gender: A preliminary investigation into the links between violence against women and HIVIAIDS in South Africa (Johannesburg: Centre for the Study of Violence and Reconciliation).

Weeks, J. (1985) Sexuality and its Discontents: Meanings, Myths and Modern Sexualities (London: Routledge and Kegan Paul). 
Wood, K., Jewkes, R. (2001) 'Dangerous' Love: Reflections on violence among Xhosa township youth. In R. Morrell (ed.) Changing Men in Southern Africa (South Africa: University of Natal Press and London: Zed Books Ltd), pp. 317-336.

Zulu, B. (2001) Sexual Violence and Coercion: Zojazem learners' (mis)perceptions (Johannesburg: Centre for the Study of Violence and Reconciliation). 